\title{
VALIDITAS PERANGKAT PEMBELAJARAN IPA BERBASIS MASALAH BERMUATAN KARAKTER
}

\author{
Tirmayasari $^{1 *}$, A.Wahab Jufri ${ }^{2}$, Ahmad Harjono ${ }^{3}$ \\ ${ }^{1}$ Program Studi Magister Pendidikan IPA, Universitas Mataram \\ ${ }^{2}$ Program Studi Pendidikan Biologi, Universitas Mataram \\ ${ }^{3}$ Program Studi Pendidikan Fisika, Universitas Mataram \\ *Email: tirmafatih@gmail.com
}

DOI: http://dx.doi.org/10.29303/jpft.v5i2.1419

\begin{abstract}
The purpose of of this study is to determine the validity of a learning tools of charactersbased problem on light and optical concept. This type of research is Research \& Development refers to Dick \& Carey model which consists of ten stages namely: identify instructional goal, conduct instructional analysis, analyze learner and contexts, write performance objektives, develop assessment, develop intrucsional strategy, develop and select instructional material, design and conduct formative evaluation of instruction, revise instruction, design and conduct summative evaluation. The formative evaluation stage was done by: the validation of the learning tools (syllabus, lesson plan, students worksheets, evaluation instruments) by three experts twice validation. Validation has been carried out by experts using a validity test instrument in the form of a questionnaire. Validity test for syllabus, lesson plan, student worksheet and evaluation instruments get results with very feasible. In conclusion, learning tools of characters-based problem on light and optical concept was feasible to be applied in science learning processes.
\end{abstract}

Keywords: Learning Tools; Validity; Problem Based Learning

\section{PENDAHULUAN}

Kurikulum 2013 menekankan pada dimensi pedagogik modern dalam pembelajaran yaitu menggunakan pendekatan ilmiah (Scientific Approach) sehingga pengetahuan, keterampilan, maupun sikap peserta didik menjadi berubah dan berkembang dari waktu ke waktu (Khaliq et al. 2015; Rahayu et al. 2016). Model pembelajaran yang dipandang sejalan dengan prinsip-prinsip tersebut adalah pembelajaran berbasis masalah atau Problem Based Learning (PBL) (Mutia \& Serevina, 2014). PBL berpengaruh bagi pemahaman konsep, keterampilan berpikir kritis, motivasi kelompok, belajar mandiri, kemampuan komprehensif, dan hasil belajar peserta didik (Liu et al., 2019; Aji et al. 2017; Hasanah et al. 2017; Li et al., 2016; Chiang et al., 2016; Husniati et al. 2016; Dewi et al. 2016; Nurqomariah et al. 2017).

Sikap ilmiah peserta didik terbina dengan serangkaian kegiatan eksperimen yang dilakukan mulai dari menyusun rumusan masalah sampai mendiskusikan permasalahan dengan kelompoknya dan menyimpulkan pendapat yang paling relevan sebagai suatu kesimpulan (Harjono et al. 2015). Sikap ilmiah yang ditanamkan melalui pembelajaran yang disinergikan dengan strategi kooperatif akan melatih pembentukan karakter siswa, hal ini dapat dibiasakan dengan bekerjasama pada saat proses pembelajaran (Khoiriyah et al. 2017). Gunawan (2015) menyatakan bahwa implikasi berkembangnya sikap ilmiah adalah berkembangnya nilai-nilai sains dalam diri siswa, yang selanjutnya akan meningkatkan berbagai kemampuan yang dibutuhkan siswa dalam kehidupan seharihari.

Pengembangan keterampilan berpikir kritis (KtBK) peserta didik jarang diperhatikan dalam kegiatan pembelajaran. Padalah keterampilan berpikir kritis mampu meningkatkan kedisiplinan siswa secara 
intelektual aktif dan terampil dalam mendukung siswa untuk mengembangkan konsep, menerapkan, menganalisis, mensintesis, dan mengevaluasi informasi (Gunawan, 2017). KtBK bisa dibangkitkan dengan membiasakan peserta didik pada pemecahan suatu masalah, pembelajaran yang menekankan pada proses perolehan konsep, berbasis penyelidikan, latihan merumuskan pertanyaan divergen, merumuskan dan menguji hipotesis, menganalisis dan menginterpretasi data, serta mengkomunikasikan hasil kegiatan ilmiah yang telah dilakukannya (Jufri \& Sulistyo, 2010; Eggen \& Kauchak, 2016).

Berdasarkan uraian di atas, maka tujuan umum penelitian ini adalah untuk menghasilkan perangkat pembelajaran IPA berbasis masalah untuk meningkatkan keterampilan berpikir kritis dan sikap ilmiah peserta didik yang layak digunakan dalam pembelajaran.

\section{METODE PENELITIAN}

Penelitian ini merupakan penelitian pengembangan (Research and Development). Prosedur penelitian pengembangan ini merujuk pada model desain pengembangan pembelajaran sains menurut Dick et al. (2009) menyatakan bahwa terdapat sepuluh tahapan pelaksanaan penelitian dan pengembangan. Tahap kedelapan yaitu merancang dan melaksanakan evaluasi formatif yang meliputi uji validitas. Validasi dilakukan sebanyak dua kali oleh 3 validator ahli. Teknik analisis data menggunakan persamaan (1):

$$
\mathrm{NA}=\frac{\mathrm{V}_{1}+\mathrm{V}_{2}+\mathrm{V}_{3}}{3}
$$

Berdasarkan nilai NA yang diperoleh, ditetapkan kriteria validitas (Ratumanan \& Laurens, 2011) seperti pada Tabel 1 berikut.

Tabel 1. Kriteria Hasil Penilaian Kelayakan dari Ahli

\begin{tabular}{lll}
\hline Rerata & Penilaian & Keputusan \\
\hline $1,00 \geq \mathrm{SV} \leq 1,8$ & Sangat kurang & Belum dapat digunakan, memerlukan konsultasi \\
& valid & \\
$1,8 \geq \mathrm{SV} \leq 2,6$ & Kurang valid & Belum dapat digunakan, memerlukan konsultasi \\
$2,6 \geq \mathrm{SV} \leq 3,4$ & Cukup valid & Dapat digunakan dengan banyak revisi \\
$3,4 \geq \mathrm{SV} \leq 4,2$ & Valid & Dapat digunakan dengan sedikit revisi \\
$4,2 \geq \mathrm{SV} \leq 5,0$ & Sangat valid & Dapat digunakan tanpa revisi \\
\hline
\end{tabular}

Perangkat pembelajaran yang disusun dapat kembangkan lebih lanjut sehingga dapat digunakan dalam proses pembelajaran minimal validasi mencapai nilai rata-rata 3,4 $\geq \mathrm{SV} \leq 4,2$ yang termasuk dalam kategori layak.

\section{HASIL DAN PEMBAHASAN}

Pengembangan perangkat melalui beberapa tahapan yaitu: (1) analisis kebutuhan dan identifikasi tujuan, pada tahap ini peneliti menentukan dan memilih kompetensi inti dan kompetensi dasar yang digunakan untuk mencapai tujuan pembelajaran. Kompetensi Dasar yang dipilih yaitu KD.3.12 dan 4.12; (2) analisis pembelajaran, menentukan kegiatan belajar yang perlu dilakukan peserta didik untuk mencapai tujuan pembelajaran dengan menggunakan model pembelajaran Berbasis masalah (probem based learning); (3) analisis peserta didik dan konteks, mengumpulkan data-data peserta didik kelas VIII untuk mengetahui karakteristiknya serta mengumpulkan data tentang sarana dan prasarana yang dimiliki oleh kedua sekolah tersebut. Peserta didik berjumlah 20 orang perkelas, karakteristiknya bahwa peserta didik tertarik dengan pembelajaran berbasis penyelidikan melalui praktikum, diskusi 
terkait fenomena-fenomena yang terjadi di lingkungan sekitar. Salah satu model pembelajaran yang membantu peserta didik terlibat secara aktif dalam kegiatan atau aktivitas penyelidikan secara langsung untuk mencari solusi terkait kejadian atau fenomena dunia nyata adalah model pembelajaran berbasis masalah (Jiniarti et al. 2017); (4) menentukan tujuan pembelajaran, dalam tahap ini peneliti merumuskan indikator pencapaian kompetensi (IPK) sesuai dengan KD yang dipilih; (5) mengembangkan instrument penilaian, instrumen yang dikembangkan bertujuan untuk mengukur variabel keterampilan berpikir kritis (KtBK) peserta didik menggunakan instrumen tes dalam bentuk uraian; Sikap ilmiah dan Karakter menggunakan instrumen angket; (6) mengembangkan strategi pembelajaran, yaitu model pembelajaran berbasis masalah;
(7) mengembangkan bahan pembelajaran, materi yang dikembangkan dalam bahan ajar adalah materi cahaya dan optik kelas; (8) merancang dan melakukan evaluasi formatif, pada kegiatan ini dilakukan validasi ahli dan uji kelompok kecil atau uji coba skala terbatas terhadap perangkat pembelajaran; dan (9) melakukan revisi sesuai dengan masukan dan saran dari tim validator serta kelemahan yang ditemukan selama proses uji coba skala terbatas.

Validasi perangkat dilakukan dua kali, baik pada validasi Pertama dan Validasi kedua terhadap silabus, RPP, LKPD, Bahan Ajar, instrumen tes keterampilan berpikir kritis, tes sikap ilmiah, anhket sikap ilmiah, dan angket karakter secara keseluruhan dengan kategori valid. Berikut disajikan rangkuman hasil validasi oleh validator ahli pada Tabel 2 .

Tabel.2 Hasil Validasi perangkat pembelajaran

\begin{tabular}{|c|c|c|c|c|c|c|c|c|c|c|}
\hline \multirow{3}{*}{ No } & \multirow{3}{*}{$\begin{array}{c}\text { Perangkat } \\
\text { Pembelajaran }\end{array}$} & \multirow{2}{*}{\multicolumn{3}{|c|}{$\begin{array}{c}\text { Validasi Pertama } \\
\text { Rata-rata Skor } \\
\text { validator }\end{array}$}} & \multirow{2}{*}{\multicolumn{3}{|c|}{$\begin{array}{c}\text { Validasi Kedua } \\
\text { Rata-rata Skor } \\
\text { validator }\end{array}$}} & \multirow{3}{*}{$\begin{array}{c}\text { Rata- } \\
\text { rata }\end{array}$} & \multirow{3}{*}{$(\%)$} & \multirow{3}{*}{ Kategori } \\
\hline & & & & & & & & & & \\
\hline & & V1 & V2 & V3 & V1 & V2 & V3 & & & \\
\hline 1 & Silabus & 4.1 & 4.1 & 4.2 & 4.3 & 4.3 & 4.4 & 4.2 & 84 & valid \\
\hline 2 & RPP & 4.2 & 4.1 & 4.0 & 4.3 & 4.4 & 4.3 & 4.2 & 84 & valid \\
\hline 3 & LKPD & 3.9 & 4.0 & 4.0 & 4.1 & 4.1 & 4.2 & 4.1 & 82 & valid \\
\hline 4 & Bahan Ajar & 3.6 & 3.6 & 3.7 & 4.0 & 4.1 & 4.1 & 3.9 & 78 & \\
\hline 5 & $\begin{array}{l}\text { Instrumen tes } \\
\text { keterampilan } \\
\text { Berpikir kritis }\end{array}$ & 3.9 & 3.9 & 3.9 & 4.3 & 4.3 & 4.3 & 4.1 & 82 & valid \\
\hline 7 & $\begin{array}{l}\text { Angket Sikap } \\
\text { Ilmiah }\end{array}$ & 3.7 & 3.8 & 3.8 & 4.2 & 4.3 & 4.3 & 4.0 & 80 & valid \\
\hline 8 & Angket karakter & 3.7 & 3.5 & 3.7 & 4.2 & 4.3 & 4.3 & 4.0 & 80 & valid \\
\hline Rata & -rata & 3.9 & 3.9 & 3.9 & 4.2 & 4.3 & 4.3 & & & \\
\hline pers & ntase & $78 \%$ & $78 \%$ & $78 \%$ & $84 \%$ & $86 \%$ & $86 \%$ & & & \\
\hline Rata & - rata keseluruhan & & 3.9 & & & 4.3 & & & & \\
\hline Pers & ntase & & $78 \%$ & & & $86 \%$ & & & & \\
\hline Kate & gori & & Valid & & & gat va & & & & \\
\hline
\end{tabular}

Tabel 2 menggambarkan hasil validasi baik validasi pertama dan Kedua, untuk setiap aspek perangkat pembelajaran yang dikembangkan seperti silabus, RPP, LKPD, Bahan Ajar, Instrumen tes keterampilan berpikir kritis, angket sikap ilmiah, dan angket karakter termasuk pada kategori valid. Pada Validasi Pertama diperoleh rata-rata skor keseluruhan sebesar 3.9 dengan persentase $78 \%$ termasuk pada kategori valid. Kemudian Perangkat direvisi sesuai saran dari validator kemudian divalidasi yang kedua kalinya sehingga diperoleh rata-rata skor keseluruhan perangkat sebesar 4.3 dengan persentase $86 \%$ termasuk pada kategori sangat valid. 
Artinya perangkat pembelajaran yang dikembangkan dapat digunakan pada pembelajaran IPA di SMP.

Perangkat pembelajaran dikatakan layak apabila memenuhi kriteria validitas isi dan konstruk (Rochmad, 2012). Validasi konstruk menunjukkan konsistensi antara komponen-komponen pembelajaran.

Komentar atau saran yang diisi masing-masing validator pada lembar validasi dan dijadikan dasar revisi untuk penyempurnaan desain awal produk yaitu: silabus, RPP, LKPD sesudah direvisi maka, komponen dan urutannya di sesuaikan dengan permen No 22 Tahun 2016, pengembangan indikator, tujuan, dan struktur tes disesuaikan dengan tujuan pembelajaran yang akan di capai, tujuan di sajikan dalam bentuk narasi yang membuat ABCD (audien, behavior, condition, dan degree), langkah pembelajaran sudah disesuaikan dengan sintak model PBL baik pada kegiatan pendidik dan kegiatan peserta didik, dan kegiatan pendidik dan peserta didik terlihat nyata sesuai dengan model PBL.

Bahan ajar, beberapa masukan yang sudah direvisi yaitu diskrispi sejajar dengan posisi gambar yang terkait, gambar disajikan dengan posisi kiri kanan agar penglihatan tidak di satu posisi saja, warna gambar sudah disesuaikan, jenis huruf dari cambria di ubah menjadi arial sehingga mempermudah peserta didik membaca, gambar yang ada batasan atau dalam kotak dihilangkan bingkainya sehingga penglihatan menjadi luas, kegiatan rumah di bagian cover di pindahkan ke dalam uraian pada sub bab bahan ajar, lembar Investigasi berisi indikator variabel penelitian yang ingin dicapai, setiap rumus diberikan urutan.

Bahan ajar merupakan salah satu elemen penting yang mempengaruhi kesuksesan proses pembelajaran (Mardiana, 2018). Pembelajaran sangat dipengaruhi oleh beberapa komponen seperti bahan ajar dan perangkat pembelajaram serta pengaturan kelas (Auliah, 2018), hal ini sejalan dengan Gunada, dkk (2015) yang menyatakan bahwa perangkat pembelajaran berbasis masalah dapat menumbuhkan sikap ilmiah.

LKPD yang dikembangkan ditulis dan disajikan secara menarik dilengkapi dengan gambar dan keterangan serta menggunakan bahasa yang baik dan benar sehingga mudah dimengerti oleh peserta didik dalam proses pembelajaran (Dewi et al. 2019; Afza, 2016).

Instrumen Penilaian, direvisi sesuai masukan dan saran dari validator yaitu soal disesuaikan dengan indikator KtBK, aspek yang di observasi telah disesuaikan dengan indikator KtBK, Sikap ilmiah, dan karakter yang akan di ukur, struktur dan redaksi soal sebagian sudah diperjelas, beberapa gambar sudah dihapus, pernyataan angket telah diperjelas, aspek yang ditampilkan disesuaikan dengan nilai-nilai pendidikan karakter.

\section{PENUTUP}

Berdasarkan hasil penelitian dapat disimpulkan bahwa proses validasi perangkat yang dikembangkan memenuhi validasi isi dan konstruk. Hal ini berarti bahwa perangkat pembelajaran yang dikembangkan layak dan dapat digunakan dalam pembelajaran IPA di SMP.

\section{REFERENSI}

Afza, A. 2016. Pengembangan Perangkat Pembelajaran Biologi Berorientasi Model Problem Based Learning (PBL) bermuatan Karakter. Jurnal BioConcetta. 2(1): 128-141.

Auliah, A. 2018. Indonesian Teachers' Perceptions on Green Chemistry Principles: A Case Study of a Chemical Analyst Vocational School. 
Journal of Physics: Conference Series, 1028, 012-042. IOP Publishing.

Aji, S.D., Hudha, M.N., \& Rismawati, A.Y. 2017. Pengembangan Modul Pembelajaran Fisika Berbasis Problem Based Learning untuk Meningkatkan Kemampuan Pemecahan Masalah Fisika. Science Education Journal, 1(1), 36-51.

Chiang, C.L., \& Lee, H. 2016. The Effect of Project Based Learning on Learning Motivation and Problem Solving Ability of Vocational High School Students. International Journal of Information and Education Technology, 6 (9), 709-712.

Dick, W., Carey, L., \& Carey, J.O. 2009. The Systematic Design Of Instruction, Seventh Edition. New Jersey Columbus: Pearson.

Dewi, S.M., Harjono, A., \& Gunawan. 2016. Pengaruh model pembelajaran berbasis masalah berbantuan simulasi virtual terhadap penguasaan konsep dan kreativitas fisika siswa SMAN 2 Mataram. Jurnal Pendidikan Fisika dan Teknologi, 2(3), 123-128.

Dewi, S.M., Gunawan, G., Susilawati, S., \& Harjono, A. 2019. Validitas Perangkat Pembelajaran Fisika Berbasis Model Generatif Berbantuan Laboratorium Virtual. Jurnal Pendidikan Fisika dan Teknologi. 5(1), 162-166.

Eggen, P., \& Kauchak, D. 2016. Strategi dan Model Pembelajaran. Jakarta: PT Indeks.

Gunada, I.W., Sahidu, H., \& Sutrio. 2015. Pengembangan Perangkat Pembelajaran Fisika Berbasis Masalah Untuk Meningkatkan Hasil Belajar dan Sikap Ilmiah Mahasiswa. Jurnal Pendidikan Fisika dan Teknologi, 1(1), 38-46.

Gunawan. 2015. Model Pembelajaran Sains Berbasis ICT. Mataram: FKIP Universitas Mataram.
Gunawan. 2017. Keterampilan Berpikir dalam Pembelajaran Sains. Mataram: Arga Puji Press.

Harjono, A., Jufri, A.W., \& Arizona, K. 2015. Implementasi Media Tiga Dimensi Kemagnetan Berbasis Inkuiri Melalui Strategi Kooperatif Terhadap Sikap Ilmiah Siswa. Jurnal Pendidikan Fisika dan Teknologi, 1(1), 15-23.

Hasanah,T.A.N., Huda, C., \& Kurniawati, M. 2017. Pengembangan Modul Pembelajaran Fisika Berbasis Problem Based Learning (PBL) Pada Materi Gelombang dan Bunyi Untuk Siswa SMA Kelas IX. Physisc Education Journal, 1 (1), 56-65.

Husniati, A., Suciati, \& Maridi. 2016. Pengembangan Modul Berbasis Problem Based Learning (PBL) disertai diagram pohon pada materi fotosintesis kelas VIII SMP Negeri 1 Sawoo. Jurnal Inkuiri, 5 (2), 30-39.

Jiniarti, B. E., Sahidu, H., \& Verawati, N. N. S. P. 2017. Implementasi Model Problem Based Learning Berbantuan Alat Peraga untuk Meningkatkan Aktivitas dan Hasil Belajar Fisika Siswa Kelas VIII SMPN 22 Mataram Tahun Pelajaran 2014/2015. Jurnal Pendidikan Fisika dan Teknologi, 1(3), 185-192.

Jufri, A.W., \& Sulistyo, D. 2010. Efektivitas Pembelajaran Sains Berbasis Inkuiri dengan Strategi Kooperatif dalam Meningkatkan Keterampilan Berpikir Siswa SMP. Jurnal Pendidikan dan Pengajaran, 17( 2), 159-165.

Khaliq, S., Alam, M.T., \& Mushtaq, M. 2015. An Experimental Study to Investigate the Effectiveness of Project Based Learning (PBL) for Teaching Science at Elementary Level. International Journal of Academic Research in Progressive Education and Development, 4 (1), 43 55.

Khoiriyah, A.J., Zubaidah, S., \& Syamsuri, I. 2017. Penerapan Inkuiri Terpimpin 
Dalam Pembelajaran IPA Untuk Meningkatkan Sikap Sosial dan Pengetahuan Siswa Kelas VII. Jurnal Pendidikan, 2 (3), 409-415.

Liu, L., Du, X., Zhang, Z., \& Zhou, J. 2019. Effect of Problem-Based Learning In Pharmacology Education: A MetaAnalysis. Studies in Educational Evaluation, 60 (1), 43-58.

Mardiana, E. 2018. Pengembangan Bahan Ajar Berbasis Pendekatan Saintifik Meningkatkan Kemampuan Literasi Matematika Siswa Pascasarjana, Universitas Negeri Malang. Prosiding Seminar Nasional Matematika. (pp.87-91). Semarang: Universitas Negeri Semarang.

Nurqomariah, N., Gunawan, G., \& Sutrio, S. 2017. Pengaruh Model Problem Based Learning dengan Metode Eksperimen Terhadap Hasil Belajar IPA Fisika Siswa Kelas VII SMP Negeri 19 Mataram Tahun Pelajaran 2014/2015. Jurnal Pendidikan Fisika dan Teknologi, 1(3), 173-179.

Rahayu, D., Pratikto, H., \& Rahayu, W.P. 2016. Pengembangan Modul Pembelajaran kontekstual Bermuatan Karakter Pada Mata Pelajaran Kewirausahaan di SMK Cendika Bangsa Kepanjen. Jurnal Pendidikan Bisnis dan Manajemen, 2(3), 225-232.

Ratumanan, G.T., \& Laurens, T. 2011. Evaluasi Hasil Belajar Tingkat Satuan Pendidikan. Surabaya: UNESA University Press.

Rohmad. 2012. Desain Model Pengembangan Perangkat dan Pembelajaran Matematika. Jurnal Kreano, 3 (1), 59-72. 